This is the post-print version of a published work. Please, cite as:

RAMON-MUÑOZ, Ramon (2020): "The expansion of branding in International marketing: The case of olive oil, 1870s-1930s", Business History, 62:1, 98-122, DOI: https://doi.org/10.1080/00076791.2017.1344224

\title{
The expansion of branding in International marketing: The case of olive oil, 1870s-1930s
}

\section{Ramon Ramon-Muñoz}

Department of Economic History, Institutions, Politics and World Economy, Faculty of Economics and Business, University of Barcelona

\begin{abstract}
Drawing on a variety of sources, this article investigates the emergence and expansion of branding in the international olive oil markets prior to World War II. It documents the rapid growth of the world trade in packaged olive oil from the 1870s onwards and shows that the main destinations of this consumer-ready product were in the Americas. In this respect, it complements previous findings based on the use of trademark registration figures. The article then argues that the expansion of canned and branded olive oil exports to the New World was the result of three interconnected factors: the mass migration of southern Europeans in the late nineteenth century and the formation of a new market on the other side of the Atlantic; significant transformations in the commodity chain of the product in the Americas during the first third of the twentieth century; and the problems of quality uncertainty and fraud in the emerging New World markets for olive oil. By analysing these factors, this study also provides evidence to further the debate on the purpose of branding and modern marketing.
\end{abstract}

KEYWORDS: Branding; international trade; migration; commodity chain; quality; uncertainty 


\section{Introduction}

Packaging, product design, branding, pricing, market research and advertising are concepts generally identified with today's modern marketing. However, historical research in the field has conclusively shown that many of these practices are less novel than they may seem. ${ }^{1}$ Although the chronology differs according to country and sector, an increasing number of scholars have argued that in the advanced world, practices of modern marketing, ${ }^{2}$ particularly branding, were already expanding rapidly in the first decades of the nineteenth century. ${ }^{3}$ Food and drink industries pioneered this expansion in western economies such as France, the UK and the US. ${ }^{4}$

The olive oil industry - an important economic activity in countries in the Mediterranean basin - was no exception to this general rule. Like other food industries, it increasingly implemented packaging, branding and advertising both in the domestic market and abroad in the second half of the nineteenth century, ${ }^{5}$ in the form of labelled and branded bottles and cans. The importance of package and label design was well understood by exporters in the early years of the twentieth century who made extensive use of sales promotion methods and segmented their product according to quality and taste.

This article extends the current scholarship on selling and marketing food products to foreign markets. The focus is on the expansion of branding in the international olive oil market between the late nineteenth and early twentieth centuries. For some business historians, the first globalisation was a period of fundamental changes in marketing, ${ }^{6}$ one that also saw major transformations in the international olive oil market. ${ }^{7}$

This article aims to answer three interconnected questions: where, why and in what quantities did olive oil firms export packaged and branded olive oil? The list of possible answers is very long, and in spite of the burgeoning research on modern marketing, none of them appear to be conclusive. Drawing on the foreign trade statistics of a large sample of countries, this article shows that between 1870 and 1938, the world trade in bottled and canned olive oil - a proxy for branded olive oil - grew more rapidly than the total world olive oil trade. The article also documents the existence of well-differentiated patterns of export marketing across foreign markets; olive oil traders made only limited use of branding and modern marketing methods in Europe and focused their attention on the

\footnotetext{
${ }^{1}$ For modern marketing, see, for example, Fullerton's general rejection of the belief that 'sophisticated marketing is a recent phenomenon'. Fullerton, 'How', 108. For the particular case of branding, Moore and Reid 'The birth', 419 argued that 'brands and branding are as old as known civilisation'. For modern retailing, Alexander and Akehurst, 'Introduction', 5 proposed 'the emergence of modern retail systems during the period 1750-1950' as the theme that connected the essays they were editing; and for modern advertising, Church 'Advertising', 641, concluded by suggesting that in Britain 'modern advertising originated during the late seventeenth century'. On the periodisation of marketing history, see also Berghoff, Scranton and Spiekermann, 'The Origins'.

${ }^{2}$ On the concept of modern marketing applied to historical research, see, among others, Church and Godley,

'The emergence', 1 and Church 'New', 407.

${ }^{3}$ There are, certainly, dissenting views regarding the chronology, as well as the typology, of firms in the genesis of modern marketing. For the particular case of branding, see Wilkins, 'The neglected', Wilkins 'When', and Duguid, 'Developing'.

${ }^{4}$ Duguid, da Silva Lopes and Mercer, 'Reading'.

${ }^{5}$ Ramon-Muñoz, 'Product'.

${ }^{6}$ See, for example, Chandler, The visible; Tedlow, New; Wilkins, 'The neglected'.

${ }^{7}$ Ramon-Muñoz, 'Specialization'.
} 
Americas, which soon emerged as the world's leading importer of bottled, canned and branded olive oil.

In the new and emerging markets of the New World, the commodity chain of the product underwent notable modifications. Importers, food processors and distributors developed new marketing strategies for olive oil: for example, importing the product in bulk to be canned and branded in the consuming markets. This strategy made its mark, especially in the US, although in the late 1920s, exporters' own brands were still present on the other side of the Atlantic, and more than $70 \%$ of the olive oil imported into the Americas had been packaged and branded in the Mediterranean basin.

Consular information, trade data, government reports, trademark registrations, business journals and company records suggest that the continued flow of canned, bottled and branded olive oil from the Old to the New World was the result of at least three interconnected factors. First, mass migration from southern Europe in the late nineteenth century created the American market for olive oil and boosted the expansion of modern marketing. Second, transformations in the commodity chain and retailers' own-branding strategies in the Americas during the first third of the twentieth century fostered a growing demand for variety and, perhaps unexpectedly, provided some advantages to the firms that were closest to the sources of supply in the Mediterranean basin. Third, quality uncertainty and the problem of fraud in the American markets caused branding to expand and, to some extent, engendered a reputation premium for the olive oil packaged and branded in southern Europe. Ultimately, these three factors contributed to explaining the expansion of branding and modern marketing in the international market for olive oil prior to World War II.

While this study examines marketing in the context of an important and relatively unexplored industry, it sheds light on several general issues on historical marketing as well. The reasons for the emergence of techniques and practices associated with modern marketing in a particular location and on a particular scale have also been widely discussed in research on branding and marketing history and remain relevant to the business sector today. ${ }^{8}$ In analysing export marketing, this study helps to explain the origin of some of the most salient features in the modern-day international marketing of olive oil.

The article is organised as follows. Section 2 provides quantitative estimates on the evolution of international trade for packaged and branded olive oil since the 1870s. It also quantitatively assesses patterns of export marketing across continents and shows that in this case its rapid expansion paralleled the growth of American markets for (Mediterranean) olive oil. The remainder of the article explores the reasons why modern export marketing boomed in the Americas. Section 3 associates mass migration and market formation with the expansion of export branding. Section 4 explores crosscontinent differences in packaging, blending and storing in a context of changes in the commodity chain and growing demand for variety. In this section, the case of the US together with Argentina, the most dynamic export market for canned and branded olive oil - receives particular attention. Section 5 deals with quality uncertainty, fraud and the

\footnotetext{
${ }^{8}$ For references, see below.
} 
responses of authorities to these challenges in the US as well as in other American markets. Section 6 concludes.

\section{Expansion of branding and modern marketing in olive oil prior to World War II}

Marketing techniques underwent dramatic transformations in the nineteenth and early twentieth centuries. In food and drink, branding and other components of modern marketing expanded in both domestic and foreign markets. The olive oil industry was no exception to this general rule. However, prior to World War II, it is extraordinarily difficult to determine exactly the extent of the use of new marketing techniques in the product's international markets, simply because statistical information is not available. Trademark agencies provide data on trademark registration, but hardly anything is known about the total number of olive oil brands operating in foreign markets. The data available on sales abroad according to firm and brand are incomplete, and the advertising expenditures of exporting firms dealing in olive oil have not been reported.

Surprisingly, the only light in the darkness comes from the foreign trade statistics of the largest importing and exporting countries. Of course, they do not offer any indications about the practice of branding, to say nothing of advertising. However, they progressively detail the weight and size of the packages that were used to trade olive oil in international markets, which appears to be a good (though imperfect) proxy for the extent of the use of modern marketing techniques in international markets.

Indeed, prior to 1938, contemporaries argued that the use of cans, bottles and other small packages was generally an indication that the product was branded, while the use of barrels, casks and other large containers was associated with trading olive oil in bulk. More recently, Alfred Chandler identified packaging with branded products, especially after the 1880s when the first automatic-line canning factory was built in the US. So, too, did Richard Tedlow, who argued that the beginning of mass brand marketing in the US was closely linked to the fact that the new machinery allowed manufacturers of consumer goods to put their own name on a large volume of small packages. And, finally, Mira Wilkins pointed out that packaged, canned and bottled foods and beverages were almost always branded in the developed world, especially between 1914 and $1938 .^{9}$

\footnotetext{
${ }^{9}$ Chandler, Scale, 63-65, 147-49; Tedlow, 'The fourth', 12; and Wilkins, 'When', 30. If packaging can be considered a proxy for branding, one is tempted to say that it can also be considered a proxy for advertising, since branding and advertising progressively became two sides of the same coin. This is, however, more difficult to prove. Advertising is related to many factors that differ from firm to firm as well as from country to country, although it is true that a larger use of branding techniques would be expected to correspond with a higher intensity in advertising.
} 


\section{Figure 1. Estimates of total world imports of olive oil in cans, bottles and other small packages, 1870-1938: Index numbers and percentages (five-year averages, original data in quantities)}

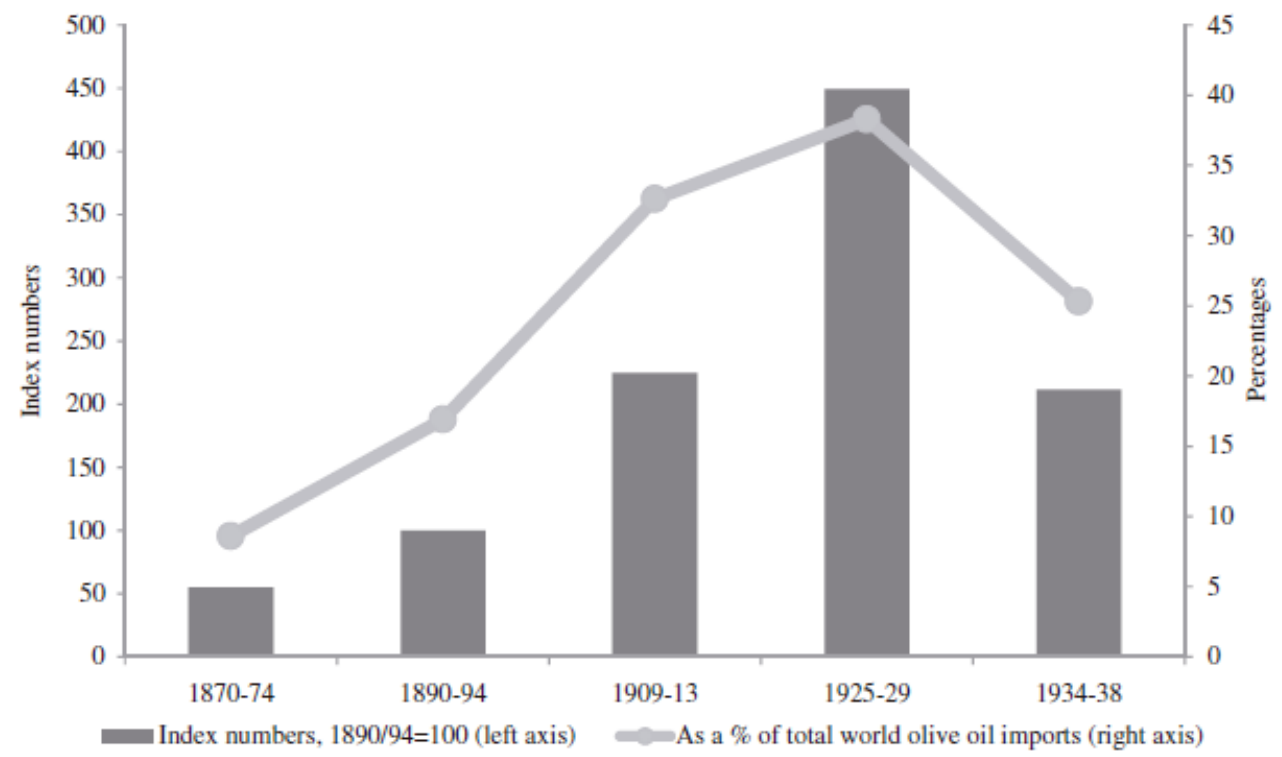

Notes and Sources: These estimates are based on import data compiled from the foreign trade statistics of a large sample of countries. Total world imports include only Europe and the Americas, by far the world's largest importers of olive oil prior to 1938. See also text and footnotes.

Using import data, Figure 1 presents estimates of the quantity of olive oil traded in cans, bottles and other small packages in the international markets for the period 18701938. ${ }^{10}$ Although rough and provisional, these estimates show that international trade in canned and bottled olive oil increased at a very rapid pace from the 1870s onwards. They also coincide with most of the existing evidence on trademark registrations in several countries in the Atlantic economy. ${ }^{11}$ Rates of growth of canned and bottled olive oil were very high, much higher than those recorded in olive oil traded in large packages. While imports (and exports) of canned and bottled olive oil approximately doubled every 20 years between 1870 and 1929, olive oil traded in large packages performed worse over

\footnotetext{
${ }^{10}$ The foreign trade statistics of the largest trading countries progressively detailed both the use and quality of the product (edible and inedible olive oil) and the weight and size of the Package used to trade it. On the basis of these sources, as well as other qualitative and quantitative information obtained from a large variety of sources, the data shown in Figure 1 and Table 1 have been estimated. These data report estimates on international olive oil imports for the period from 1870-74 to 1934-38 distinguishing by packages (large and small) and continents (Europe and the Americas, which accounted for more than 90 per cent of total world olive oil imports). The sample countries for Europe are Austria-Hungary (only up to 1914), Belgium, Bulgaria (excluding 1870-1874), Czechoslovakia (only after 1919), France, Germany, Hungary (only after 1919), Italy, Norway, Portugal, Romania (excluding 1870-1874), Russia (only up to 1913), Switzerland and the United Kingdom. For the Americas, the sample includes Argentina, Brazil, Chile (excluding 18701874), Cuba, Mexico (excluding 1870-1874), Peru (excluding 1870-1874), Uruguay (excluding 18701874), the US and Venezuela (excluding 1870-1874 and 1890-1894). When necessary, data from the foreign trade statistics of Spain as well as of other exporting countries have also been considered in the estimates. As a rule, and in accordance with the information available, it has been assumed that olive oil imported for industrial uses was traded in large packages. For more details on methods and sources, see Ramon-Muñoz, 'Patterns'

${ }^{11}$ Da Silva Lopes and Guimaraes, 'Trademarks', Duguid, da Silva Lopes and Mercer, 'Reading'; Higgins, 'The making'; Lluch 'Marca'; Mercer, ‘A mark'; Sáiz and Fernández, 'Catalonian'.
} 
the same period, particularly prior to 1913. As a result, canned and bottled olive oil increased its share in international markets: in the early 1870s, for example, it accounted for less than $10 \%$ of total world olive oil imports, but by the early 1890s, this proportion had risen above $15 \%$. By the second half of the 1920s, around $40 \%$ of all the olive oil put on the international markets was traded in cans and bottles of different weights, sizes and shapes. After 1929, this international trade fell dramatically, as did trademark registrations in Argentina, France, the UK and the US, but this was because of the exceptional circumstances in the wake of the Wall Street crisis. Indeed, following the 1929 crash, tariffs on canned and bottled olive oil were generally higher than those on oil traded in bulk, and therefore had a greater impact on the former's sales.

Taking the period 1870-1938 as a whole, there is no doubt that there was a boom in the international trade in branded olive oil and a rapid expansion in the use of modern marketing in olive oil exports. However, this expansion had its limits. The estimates presented in Figure 1 show that the quantity of olive oil traded in cans and bottles through the international markets never surpassed the amount commercialised in bulk. A nonnegligible share of this bulk olive oil was bottled, canned and branded on arrival in its destination and reached the final consumer in the form of salad or table oil, an issue that will receive further attention below.

Table 1. Estimates of olive oil imported in cans, bottles and other small packages in Europe and the Americas, 1870-1938 (five-year averages, original data in quantities)

\begin{tabular}{|l|r|r|r|r|r|r|}
\hline Periods & \multicolumn{2}{|c|}{$\begin{array}{l}\text { As a percentage of total olive oil imports } \\
\text { in cans, bottles and other small packages }\end{array}$} & \multicolumn{3}{|c|}{ As a percentage of total olive oil imports } \\
& \multicolumn{1}{|c|}{ Europe } & \multicolumn{1}{|c|}{ America } & \multicolumn{1}{c|}{ Total } & \multicolumn{1}{c|}{ Europe } & \multicolumn{1}{c|}{ America } & \multicolumn{1}{c|}{ Total } \\
\hline $1870-1874$ & 8.2 & 91.8 & 100.0 & 0.8 & 87.5 & 8.6 \\
\hline $1890-1894$ & 10.8 & 89.2 & 100.0 & 2.3 & 88.6 & 17.7 \\
\hline $1909-1913$ & 10.9 & 89.1 & 100.0 & 5.7 & 74.5 & 32.1 \\
\hline $1925-1929$ & 9.3 & 90.7 & 100.0 & 6.8 & 73.2 & 38.3 \\
\hline $1934-1938$ & 11.1 & 88.9 & 100.0 & 4.7 & 56.5 & 25.3 \\
\hline
\end{tabular}

Notes and Sources: See Figure 1.

Export patterns differed across markets. Table 1 provides evidence on imports of bottled and canned olive oil by distinguishing between Europe and the Americas, the world's two largest olive-oil-importing regions. The data are presented in percentages, and speak for themselves: the largest foreign markets for bottled and canned olive oil were in the New World, where the product arrived mainly in cans and other small packages. It is also clear that the olive oil trade differed enormously on the two sides of the Atlantic, at least in terms of packaging. Certainly, the period 1870-1938 saw a certain convergence in trading patterns, as the percentage of olive oil imports in cans, bottles and other small packages relative to total olive oil imports increased in Europe and tended to decrease in the Americas; even so, in the late 1920s the Americas were still the destination of more than $90 \%$ of all the canned and bottled olive oil exported from the Mediterranean basin. Similarly, American markets continued to import bottled and canned olive oil, which, on average, accounted for around three-quarters of the total olive oil introduced into the continent. By contrast, in the late 1920s, Europe still accounted for more than $75 \%$ of the total world olive oil trade in barrels or casks and, in addition, continued to import olive oil in bulk, since only $7 \%$ of the total quantity of oil imported was in cans and bottles. 
This evidence suggests that export marketing clearly differed on the two sides of the Atlantic. Extensively used in American markets, branding and other modern marketing techniques appear to have been applied far less by exporters trading olive oil towards Europe.

Of course, Europe and the Americas were not the only regions where olive oil was marketed. In Asia and Oceania, some olive oil was imported as well, and, in Asia at least, it mostly arrived in cans and bottles. ${ }^{12}$ Cans and bottles were also mainly used to export olive oil to some African countries. For example, prior to World War I, most of the olive oil exported to Egypt consisted of bulk olive oil, of which a certain amount was used in the domestic soap industry. Exports to Tunisia, an important olive oil producer in its own right, comprised a combination of branded and bulk olive oil, though bulk olive oil appears to have predominated. ${ }^{13}$ Nonetheless, Africa, Asia and Oceania were minor destinations for olive oil; in 1909- 1911, they accounted for tiny proportions of world olive oil imports, namely $2.5,0.3$ and $0.2 \%$ respectively compared with figures of $54 \%$ for Europe and $43 \%$ for the Americas. ${ }^{14}$

Why did the patterns of export marketing differ so markedly in America and Europe? One obvious reason is to do with demand. In Europe, olive oil was mainly traded outside the producing countries as a raw material. For example, in France and Italy, the two leading importers as well as two important producers, the bulk of olive oil was imported for refining, blending, packaging and, finally, re-exporting. In northern Europe, the low demand for table and kitchen olive oils, together with the characteristics of the distribution systems and a discriminatory tariff policy on canned and bottled olive oil, significantly limited the use of modern packaging, branding and advertising techniques. ${ }^{15}$

The American pattern of demand was different. From the late nineteenth century onwards, a growing amount of olive oil crossed the Atlantic to be consumed as salad oil and for other cooking purposes. It still remains unclear why, for the most part, exporting firms decided to package and brand their product before dispatching it; they could have sent it from the Mediterranean basin to the Americas in bulk and then packaged, branded and sold it to the final consumer. While a certain amount of the product did arrive in bulk, about three-quarters of the total imports were already packaged and branded. The remainder of this article is devoted to explaining the reasons for this pattern of export marketing.

\section{Mass migration and modern marketing in the Americas}

Until the last decades of the nineteenth century, the consumption of olive oil remained at very low levels in the Americas. This situation changed after the 1870s with the arrival of a mass movement of migrants from southern Europe crossing the Atlantic. Clearly, the three decades prior to 1913 represented a period of rapid growth for olive oil trade in the Americas (Figure 2), while the opposite was true for northern Europe.

\footnotetext{
${ }^{12}$ Ministero di Agricoltura, Industria e Commercio (hereafter MAIC), 'Il commercio', 3-38.

${ }^{13}$ MAIC, 'Il commercio', 44-101.

${ }^{14}$ Author's own estimates from International Yearbook, various issues.

${ }^{15}$ Ramon-Muñoz, 'Patterns'.
} 
Perhaps not surprisingly, the mass migration from southern Europe to the New World in the late nineteenth century paralleled the emergence of modern marketing in the Americas. Although in the 1880s (and even before) several brands were already well established in the largest American markets, it seems obvious that this new mass migration represented a new challenge for the competitive strategies and the marketing techniques of exporting firms.

\section{Figure 2. Aggregate Southern European immigrants' stock and gross olive oil imports in the Americas, 1870-1914 (five-year averages)}

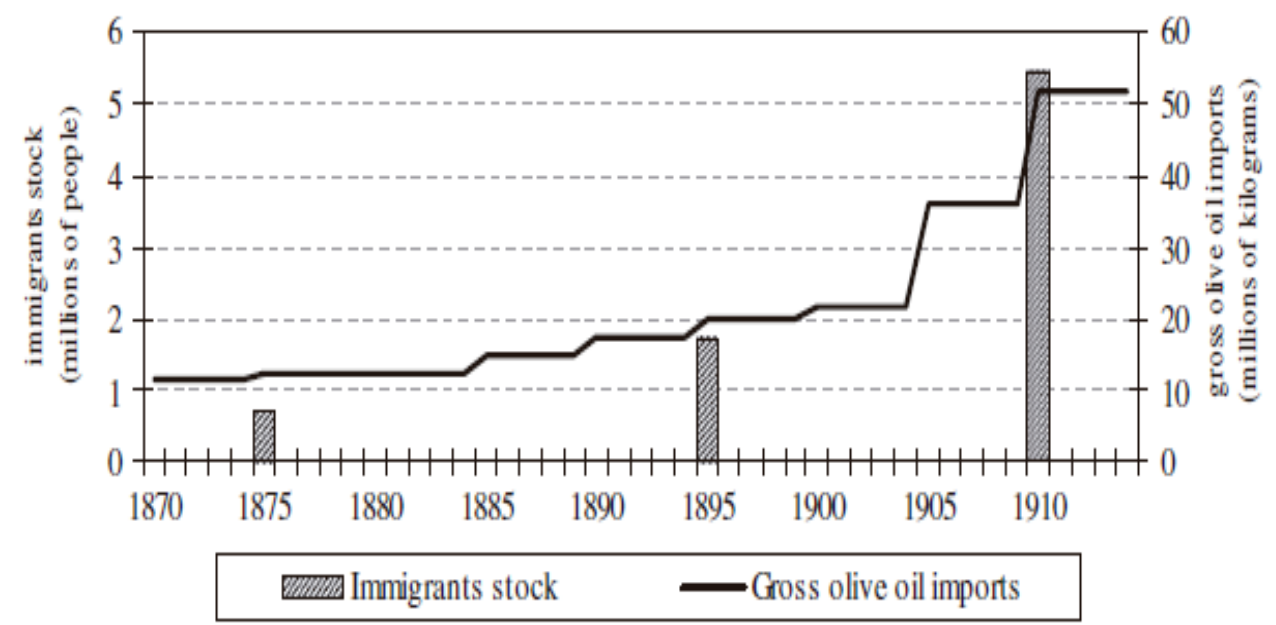

Notes and Sources: Gross olive oil imports are estimates based on trade data collected from the foreign trade statistics of the largest olive oil importing countries in America, namely Argentina, Brazil, Chile, Cuba, Mexico, the US and Uruguay. When necessary, these import data have been complemented with trade data from the foreign trade statistics of France, Greece, Italy, Portugal and Spain as well as the International Yearbook. The figures for the stock of immigrants have been taken directly from the Population Censuses of the American countries mentioned above. In the case of Brazil, the stock of immigrants has been estimated on the basis of gross immigration data. A complete and detailed list of the sources used in the estimation of these figures can be found in Ramon-Muñoz 'Patterns of export', appendix; and Ramon-Muñoz 'Migration and trade', appendix.

Between 1880 and 1913, more than 10 million people left southern Europe to settle either permanently or temporarily in the New World. ${ }^{16}$ As olive oil was a key element in the diet of Italians, Spaniards, Portuguese and Greeks, exporting firms suddenly saw that this far-off but rapidly growing market represented a huge opportunity. ${ }^{17}$ Persuading potential consumers to buy their products rather than those of their competitors became an essential task for exporters who strove to highlight the quality of their oil. Consumers had to be able to distinguish the olive oil supplied by a particular firm, and branding, together with packaging, labelling and advertising, was a means to achieve this. ${ }^{18}$ It also allowed exporters to attempt to establish a sort of link with the migrants' country of origin;

\footnotetext{
${ }^{16}$ Ferenczi and Willcox, International. See, among others, Hatton and Williamson, 'The issues', on the nineteenth century European mass migration.

17 See Ramon-Muñoz, 'Migration', and Fernández, Un 'mercado étnico', for the particular case of Argentina.

${ }^{18}$ Wilkins, 'When'.
} 
appealing to their loyalty, or at least to their familiarity with the product, might persuade consumers to purchase a particular brand and thus increase the firm's market share.

Unfortunately, the evidence available at firm level is very fragmentary, but it suggests that several exporting firms rapidly understood the potential benefits of promoting a cultural identification between olive oil and the home country of the new immigrants. Brands therefore promoted both tangible and intangible characteristics of the product; ${ }^{19}$ brand names, symbols and label designs would often evoke famous areas of olive oil production in the Mediterranean. ${ }^{20}$ This practice might even be manipulated: in Brazil, for example, with its very large Portuguese community, both the Portuguese Chamber of Commerce and Industry in Rio de Janeiro (in 1916) and the Spanish attaché (in 1925) reported that olive oil that had been canned, labelled and branded in Spain and exported to Brazil was being marketed under Portuguese-sounding brand names. ${ }^{21}$

To sum up, the mass migration from southern Europe in the late nineteenth century encouraged olive-oil-exporting firms to make more intensive use of packaging, branding and advertising. ${ }^{22}$ These and other marketing techniques served firms both to inform consumers and to earn their loyalty. Thus, information and persuasion were not contradictory goals, although in their efforts to win over consumers, some firms were quite liberal with the truth regarding the origin of the products. ${ }^{23}$ The fact is that, through branding and other modern marketing techniques, Mediterranean olive oil firms were able to differentiate their products from those of their competitors. Of course, the mass migration from southern Europe also caused the American market for olive oil to expand; this attracted new Mediterranean firms, increased competition and, in turn, intensified the use of modern marketing techniques as a competitive strategy. Not surprisingly, one outcome of applying branding and modern marketing was that barriers to entry increased; by 1930-1934, entry barriers were on average higher in the New World than in the Old World and were mainly influenced by product differentiation. ${ }^{24}$

\footnotetext{
${ }^{19}$ On this issue, see, for example, the summary by da Silva Lopes Global, 5-7.

${ }^{20}$ Tolman and Munson, 'Olive oil', 56-59.

${ }^{21}$ Câmara Portuguesa de Comércio e Indústria do Rio de Janeiro, Inquérito, 301-2 and Consejo de Economía Nacional, El aceite de oliva, 11.

${ }^{22}$ This process might also be expected in colonial territories. Late-nineteenth century colonialism also encouraged European settlement abroad; when the new settlers came from olive oil producing countries such as France or Italy, the demand for southern European oil in the newly colonised territories might have been expected to increase, contributing both to the creation of new markets for olive oil and the expansion of branding and other modern marketing techniques. More research into this issue is needed, but at present there is no clear evidence to support this hypothesis; in fact, French olive oil exports to its colonial possessions declined between the periods of 1897-1899 and 1909-1913. The only colonial territory where the consumption of French olive oil appears to have significantly increased was Tunisia, a French protectorate since 1881 as well as an emerging producer and exporter of olive oil. In this respect, and for the case of the wine industry, James Simpson has argued that 'the vine followed European settlement in the New World and North Africa' (Simpson, 'The Emergence', 267). For the case of the olive oil industry, the picture is slightly different: the European settlers certainly promoted the olive oil industry in northern Africa, but the New World remained highly dependent on the supply of Mediterranean olive oil.

${ }^{23}$ Casson, 'Brands', 42.

${ }^{24}$ Ramon-Muñoz, 'Product'.
} 


\section{Transformation of the commodity chain: the case of the US}

Mediterranean exporters were not alone in using modern marketing techniques. As the market grew, an increasing number of importers, wholesalers and retailers began to create their own brands of olive oil, even though the product continued to be packaged and labelled in the Mediterranean basin by exporting firms. There are many instances of this practice, which, in addition, covers a large number of importing countries, including Uruguay, Peru, Argentina, Brazil and the US. ${ }^{25}$ Other merchants went a step further. By the time of World War I, importers, canners and other food producers and distributors had built their own plants in the consuming countries to carry out filtering, blending, repackaging and labelling operations with olive oil imported from abroad. ${ }^{26}$ As will be shown later, other food merchants acted in a similar way, but this time building plants in the olive oil-producing countries and from there exporting a ready-packaged product to the final market, either under their own brands or packaging for brands owned by retailers in the Americas. Clearly, the commodity chain for canned and branded olive oil was changing.

This transformation is well documented in the US. It was a partial result of more general changes in markets and technology including the introduction of automatic-line canning technology in the food industry. In a context of population growth, increasing per capita income, transport improvements and technological change, ${ }^{27}$ the production of canned and branded products expanded and new sources and forms of demand for olive oil emerged. The rapid growth of canned products such as fish, mayonnaise, salad dressings

\footnotetext{
${ }^{25}$ For Uruguay, see for example, Mercurio. Revista Comercial Ibero-Americana, No. 167 (January), 1913 and El Aceite de Oliva de España (hereafter AOE), No. 49 (December), 1932, 347. For Argentina and Peru, see MAIC, Il commercio, 186-87, 384. According to an Italian consul in Argentina, once a firm had established its own brand '[retailers and importers] can enhance their sales and obtain major profits, which would be more difficult to achieve if consumers bought the same brand of olive oil from other retailers, [In addition, ] 'the same type and quality of olive oil [is] sold under different names'. MAIC, Il Commercio, 186-87. The translation is mine. For Brazil, Hijos de J. Sabater, a Spanish exporting firm, acknowledged in the mid-1920s that they were both producing and exporting seven different brands of olive oil for Brazil; two of them belonged to the firm itself but the other five were property of different Brazilian importers. Sabater was not alone in applying this strategy. According to his agent in Rio de Janeiro, this was an extended practice for many Spanish firms exporting olive oil to Brazil (Arxiu Comarcal del Baix Camp. Fons Sabater (hereafter ACBC. FS). Letter from Rio de Janeiro dated 8 July 1926). For the US, see, among others, Tolman and Munson, 'Olive oil', 53-59 and Espuny, De Gallur, 51, who refers to the case of the firm Giacomo Costa fu Andrea, from Genoa, one of the largest exporters of canned olive oil to the US in the late 1920s. According to T. Espuny, a Spanish businessman, in 1929 Costa exported 35,000 boxes to the US, of which 5,000 contained a high-quality olive oil sold under the brand Costa and 15,000 consisted of olive oil of lower quality sold under the brand Dante, which was also owned by this Italian company. The other boxes $(15,000)$ contained olive oil packaged and exported by Costa under brands owned by several importers.

${ }^{26}$ The strategy of establishing warehouses in the largest producing areas seems to have been followed by a number of US firms. Musher \& Co, for example, which opened for business in New York in 1907, imported about 1,300,000 gallons of olive oil in bulk in 1919, around 14\% of all bulk olive oil imports. In 1921, the company president Nathan Musher stated that 'Musher \& Co. maintain very expensive warehouses throughout Spain and Italy, where the oil is brought in by local farmers and immediately placed in tiled tanks and kept at an even temperature, a from the light and air, which are detrimental to olive oil' (US Congress, Tariff information, 240. Heinz (H.J.) \& Company, the well-known US food processing firm, also invested in the olive oil business abroad. In the early 1930s, the Spanish attaché in Texas noted that 'Spanish olive oil imports to the South of the United States are almost totally made by means of Heinz (...), who (...) has its own house in Spain'. AOE, No. 73 (November), 1934, 377.

${ }^{27}$ Chandler, The visible; Chandler, Scale; Tedlow, New.
} 
and sauces increased demand for vegetable oils, including, if only modestly, (bulk) olive oil. $^{28}$

The packaging and canning industry also required olive oil of different qualities and grades for sale as a salad oil. A share of this new demand came from processors and distributors of a large variety of food products, among them the well-known H. J. Heinz $\&$ Co. For these companies, which had integrated canning and distribution into their operations, packaging and selling olive oil represented an opportunity to capture a share of the growing olive oil demand and probably also to exploit economies of scale and scope in production and distribution, since the integration of new product lines helped to ensure the continuing throughput of the canning plants.

Alongside the large can-making companies and food processors, American olive oil importers also began to participate in packaging operations. Indeed, from the beginning of the twentieth century, and boosted by a discriminatory tariff against bottled and canned olive oil imports, some olive oil importers reinvented themselves as olive oil processors, taking over functions that had been previously carried out by exporters in the countries where the oil was produced. However, prior to 1914, these functions were limited to a few firms that had commenced the packaging of olive oil in cans and bottles in the US and not in the countries of origin. With the outbreak of World War I, a larger number of importers found it necessary to set up plants in the US and to install machinery for filtering and packaging foreign olive oil in cans and glass bottles of different sizes and shapes. ${ }^{29}$ These new plants were situated near the North Atlantic seaboard cities of Baltimore, Boston, Philadelphia and, above all, New York - that is, close to the main areas of olive oil consumption and trade.

Heavily dependent on continuous supplies of foreign olive oil and a certain degree of tariff protection, the US olive oil packaging industry operated throughout the interwar period. It is true that the quantity of olive oil imported for packaging remained relatively stagnant during the 1920s, as will be shown later. Nonetheless, an estimate from the US Tariff Commission suggested that in 1928-1930, about 60\% of the bulk olive oil imported into the US was consumed by the olive oil packaging industry; the remainder was bulk olive oil for fish-canning and other food industries or for blending with other vegetable oils, and a very small part was given over to technical uses. ${ }^{30}$

Notable as they were, one might have expected importers and canners' strategies of packaging olive oil in the Americas to have extended even further over the course of the twentieth century. Importing bulk olive oil was less expensive than importing packaged olive oil, partly because transport costs were lower for bulk olive oil and also partly because specific tariff duties tended to favour it. In spite of this, in the late 1920s most of the American brand-owners still preferred to import olive oil in small packages ready for final distribution and consumption rather than filter, blend and package the product in the

\footnotetext{
${ }^{28}$ In 1931, for example, information concerning the result of operation of 27 plants packaging Maine sardine (herring) shows that sardines in olive oil only accounted for $0.2 \%$ of the total product value, whereas in the case of sardines in cottonseed oil the figure was $45 \%$. Olive oil. Official organ of the olive oil industry published monthly by the Olive oil Association of America (hereafter OAA), 5, No. 9 (September, 1932), 9 .

${ }^{29}$ US Congress, Tariff Information, 240-41.

${ }^{30}$ US Tariff Commission, Report, 8.
} 
consuming market, and the same could be said for most American food producers, importers and retailers working with olive oil. By 1925-1929, the volume of edible olive oil imported in bulk in the US accounted for $40 \%$ of total edible olive oil imports, while olive oil imported in cans, bottles and other small packages represented $60 \%$. In the American continent as a whole, these proportions were around $25 \%$ and $75 \%$ respectively (Table 1).

Figure 3. US tariff duties on olive oil by packages under the tariff acts of 1897-1934 (specific duties)

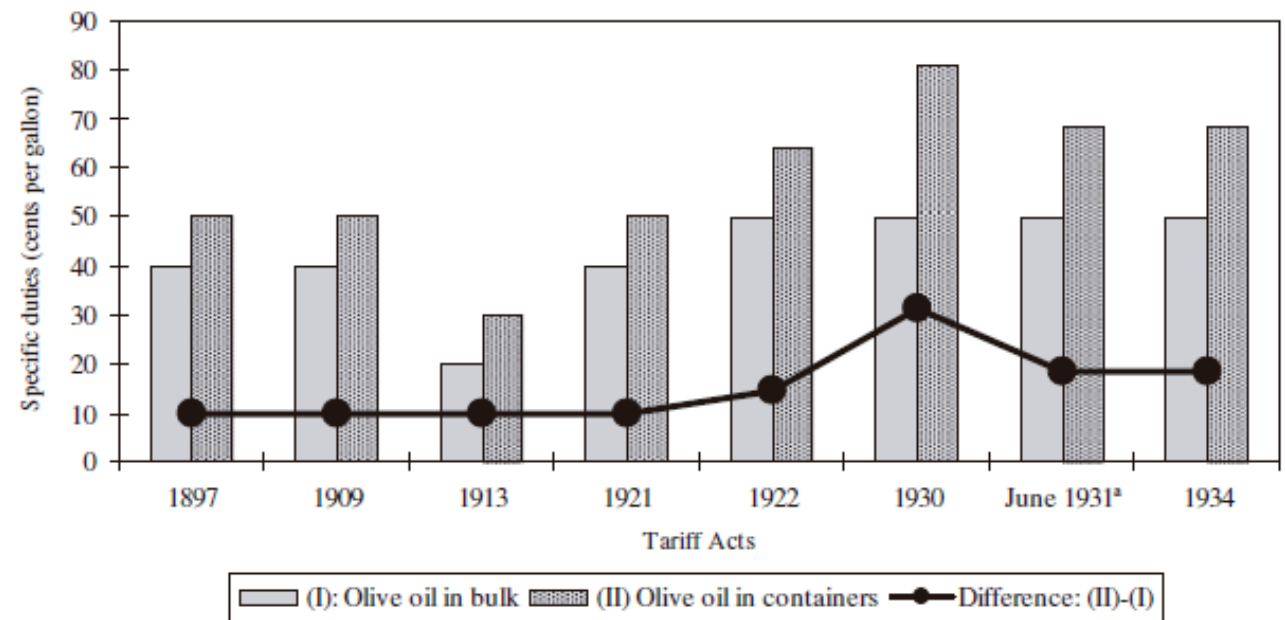

Notes and Sources: ${ }^{a} 1931$ corresponds to a Proclamation by the President regarding the US's decreasing rate of duty on olive oil weighing less than forty pounds with the immediate container, Washington 24 June 1931. Calculated from US Tariff Commission, Report to the President, 5, 19-20; and The Foreign, various issues.

The simple, obvious reason why olive oil continued to be mostly imported from Europe in cans and bottles for consumption in the Americas was that the cost of packaging was lower in Europe. This is at least what the US packagers of olive oil argued after World War I; according to them, in the 1920s lower labour costs and lower costs of packaging materials gave European olive oil exporters the opportunity to undersell the Americanpackaged product.

Although perhaps correct, the US packagers' view has to be considered with some care. In the hearings before the Tariff Act of 1929, the American packagers called for an increase in the tariff duties imposed on olive oil imported in small packages. In fact, the American packaging industry already enjoyed a certain protection; since the Tariff Act of 1897, olive oil imported in small packages had been taxed at 10 cents per gallon more than olive oil imported in bulk. This difference was maintained in the subsequent tariff acts of 1909 to 1921 and was increased to 14.5 cents per gallon in the 1922 act (Figure 3). Nevertheless, in 1929, R.U. Delapenha, who represented the US olive oil packagers working with containers weighing less than forty pounds, concluded that: 'the differential 
at present existing is not sufficient to protect the American packer' since packaging abroad, even including American duties, was cheaper than packaging in the US. ${ }^{31}$

Of course, American importers of olive oil in small packages offered a very different view. They argued that while the labour costs in the US were higher, this factor was negligible owing to the better machinery used by the US packaging industry and also owing to the fact that only non-skilled manual labour was required. As a result, costs of cans and wooden cases in the US were slightly lower than abroad or, at the most, about the same. ${ }^{32}$ However, if the existing duty was taken into account, 'domestic [packagers would] have enjoyed for the last six years a protection superior to the real difference existing [between] the cost of packaging abroad and the United States of America [which would explain why domestically packaged] olive oil [was] being sold at 10 to 20 cents per gallon cheaper' than foreign packaged olive oil. ${ }^{33}$

Figure 4. Cost differences in packaging olive oil in the US and abroad, 1928-1930 (amount by which the US costs exceeded foreign costs)

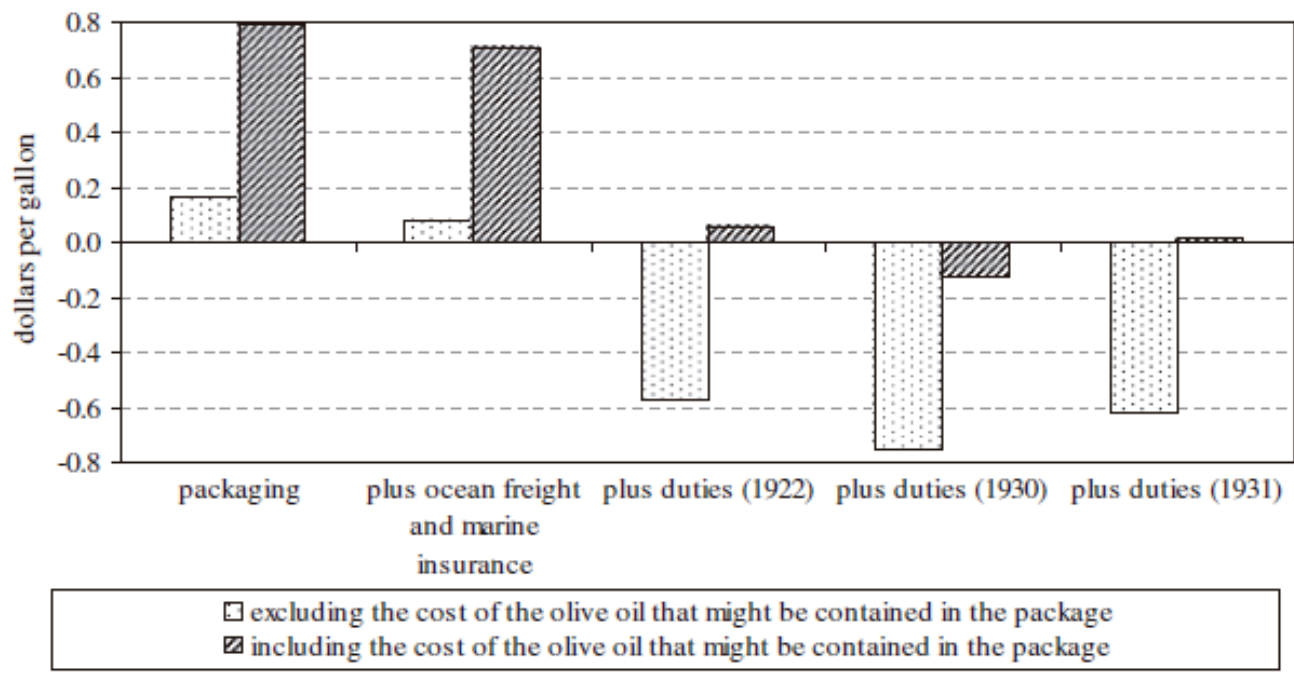

Notes and Sources: See Figure 3.

Were American importers of canned olive oil correct? Fortunately, a detailed (and apparently independent) investigation carried out by the US Tariff Commission for the period of 1928-1930 helps to throw some light on the issue. According to the figures provided by the Commission, the average costs of packaging in the US exceeded foreign costs by around 15 cents per gallon (Figure 4). This difference increased if the cost of the olive oil to be contained in the package was included in the calculations, because the olive oil was imported in bulk from southern Europe and represented around $80 \%$ of the total costs of the US olive oil packaging industry. Of course, the differences in cost begin to

31 US Congress, Tariff Readjustment, 706. In 1913, however, the representative of the Pompeian Corporation, from Baltimore M.D., argued that 'the 10 cents per gallon differential not only protects the manufacturers of packages and labels used in packaging olive oil, but gives the American packager a chance to spend a little more on packaging the olive oil under better conditions'. US Congress, Tariff Schedules, 121.

${ }^{32}$ US Congress, Tariff Act, 241-43, 248-49, 259-61; US Congress, Tariff Readjustment, 712-29.

${ }^{33}$ US Congress, Tariff Readjustment, 714. 
decrease if ocean freight and marine insurance are added to the calculation of the oil packaged abroad.

However, the decrease in the differences only becomes significant when, in addition to ocean freight and marine insurance, US tariff duties are included. For example, according to the duties fixed in the Tariff Act of 1922, the difference between olive oil packaged in the US and abroad (including the oil contained in the package) was minimal, around 0.6 cents per gallon; but if the oil was not included, the American packaging industry had an advantage of 6 cents per gallon. To some extent, the aim of the US tariff policy seems to have been the equalisation of foreign and domestic costs of packaged olive oil, at least in the interwar period. Thus, occasional cost advantages for domestic packagers deriving from excess protection tended to be corrected by reducing specific duties in order to equalise domestic and foreign costs, as was the case with the Tariff Act of 1930 and the subsequent reduction of duties in the Presidential proclamation of June 1931 (Figure 4).

Consequently, the evidence suggests that although the cost of packaging was lower in Europe than in the Americas, tariff duties tended to reduce these differences, at least in the US. If the cost of packaging (plus tariffs) was about the same, other factors should obviously be taken into account to explain why firms continued to export olive oil from Europe in small packages and under brand names instead of trading bulk olive oil to be repackaged in the Americas.

One of these factors was probably the quality of blending and storage in Europe, and another the growing demand for variety in the US over the first third of the twentieth century. Why did demand for variety emerge? Together with income growth (which is generally considered to boost demand for variety), mass migration from southern Europe in the late nineteenth century created marked differences in tastes and income in the New World and among potential consumers of olive oil, most of them of Italian origin or from other countries bordering on the Mediterranean basin. Though these factors were undoubtedly important, a final aspect needs to be stressed: the transformation of the commodity chain, described above in this section, and importers' and retailers' brandowning strategies which increased demand for variety and caused product differentiation to rise. Suppliers soon faced the challenge of producing several different varieties of olive oil, which, in addition, had to remain constant over time - no easy task, considering the characteristics of the product.

Like other agricultural goods, olive oil has always been a product with a wide quality range. There are a number of reasons for this: there are a large number of fruit varieties, which, in the period that interests us, were grown in areas that differed widely in terms of climate, soil and other natural conditions. The methods used in harvesting olives, the technology used in the crushing and pressing and, last but not least, the storage of both the fruit and the final product all differed from one region to another. All these factors influenced the product's taste, colour and acidity level, which, in addition, might vary from one year to another owing to the vagaries of the climate and (on occasion) the presence of disease. As a result, harvest fluctuation was another characteristic of olive and olive oil production, which might lead to shortages in the supply of particular varieties of olive oil. 
The use of appropriate blending practices and easy access to sources of supply was essential in order to guarantee variety among the different commercial products, but also at the same time a degree of uniformity. Expert blenders were needed both to create a homogeneous product and to produce a larger number of commercial varieties of olive oil. $^{34}$

Of course, the location of skilled labour does not necessarily determine the location of a processing or exporting industry. In olive oil, as in many other sectors, skilled labour was a mobile factor; in addition, American workers could learn blending techniques. Finally, the diffusion of olive oil industrial refineries from the first decade of the twentieth century onwards made the production of unobjectionable olive oils possible and allowed better adjustment of the oil to the specific tastes of the consumer markets. Nevertheless, it is also true that if a great variety of different products were required, proximity to the source of supply made blending operations easier. The words of Charles A. Tossi, vice-president of P. Pastene \& Co, during the hearings of the US tariff act of 1929, are highly illustrative in this respect:

"[olive oil]...varies in its characteristics from year to year, and as a uniform type is demanded by the consumer, it is necessary to blend oil from different sections in order to maintain the uniform type packed in small containers in which it is sold direct to the consumers. It was because of that fact (....) that we shifted our packing operations abroad and closed our plant in New York. With supplies available at any time and in any quantity, packing in Italy avoided the necessity of carrying tremendous stocks and the risk of running short of certain types of oil required in our blends. In this connection, it might be interesting to state that our experience of many years has taught us that it requires a minimum of three and as many as seven different types of oil to maintain our blends uniform from year to year. As we pack possibly 200 brands for customers in the United States alone, and the tastes of these customers vary, requiring different blends of oil, the logical place for a factory is at the source of the supply, rather than at 4,000 miles distance". 35

On the eve of World War I, this firm had olive oil and packaging plants in Italy. With the outbreak of war, it brought its packaging plant to New York, partly because of the war itself and partly because of the embargoes placed on exports by the Italian government. The end of the war and the removal of these embargoes provoked a new change in the marketing strategy of the firm. The managers decided to close the plant in New York and to return the packaging operations to Italy - not because packaging was more economical in Italy than in the US, but because the firm had to have large and varied supplies of olive oil at its disposal in order to meet its varied demand. Consequently, for some American firms, it might have been more useful to be next to the sources of supply (and to carry out packaging there) rather than close to the consumption markets.

Tossi's statement helps to explain why canned and branded olive oil was exported from the Mediterranean basin to the US markets. It also illustrates two of the issues raised

\footnotetext{
${ }^{34}$ US Congress, Tariff Act, 259-61.

${ }^{35}$ US Congress, Tariff Readjustment, 721. P. Pastene and Co. was a company established in Boston in 1874. By the late 1920s, it had become one of the largest distributors of imported groceries in the US and Canada.
} 
above: the emerging role of American merchants and retailers in the commodity chain, and the rapid expansion of brands owned by non-Mediterranean firms. These important transformations represented a serious threat to the market share of Mediterranean exporters' brands and one might hypothesise that, in the end, merchants' and retailers' own brands sold more packaged olive oil than the brands owned by Mediterranean exporters. ${ }^{36}$ While this might have been the case in some years after 1914, the truth is that most of the brands registered (and perhaps most of the brands operating) in the US belonged to American firms.

Figure 5 displays data on trademark registration for olive oil in the US in 1905, 1915, 1925 and 1935, that is, from the year in which a new trademark federal law was enacted until after the New York stock market crash of 1929. ${ }^{37}$ Although the figures are approximate, they make it clear that trademark registration grew rapidly between 1905 and 1915, peaked in the 1920s and collapsed in the 1930s, confirming the trend outlined in previous sections. These data also clearly illustrate that American firms and citizens, especially of Italian origin, owned most of the trademarks for olive oil registered in the first third of the twentieth century and accounted for more than three-quarters of the total registrations approved in the years under consideration.

\section{Figure 5. Number of trademarks for olive oil registered in the US by origin of the brand-owner in selected years, 1905-1935.}

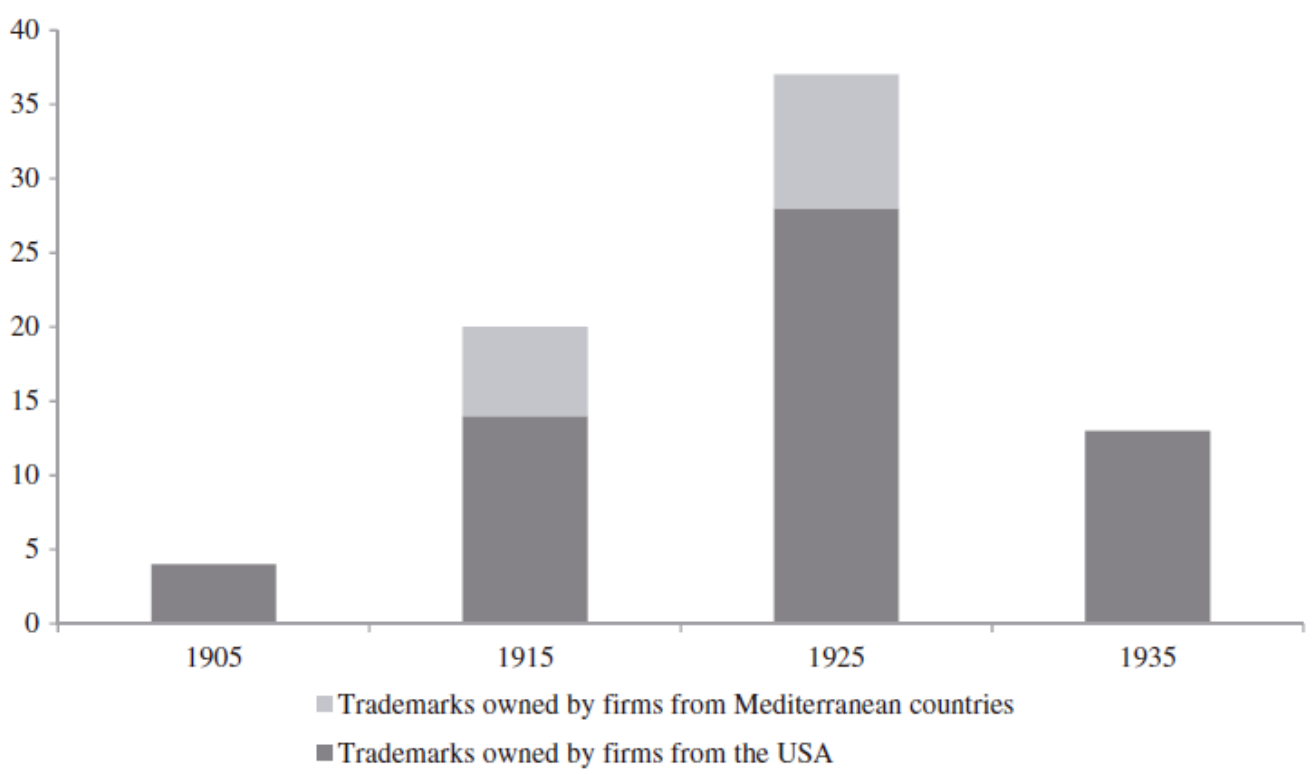

Notes and Sources: See text and footnotes.

\footnotetext{
${ }^{36}$ For the role of retailers' own brands, see, for example, Wilkins, 'When', and Williams, 'Multiple'.

37 The numbers included in this figure must be considered approximate. The Annual report, the Index of trademarks and the database of the US Patent and Trademark Office, the sources used to create this figure, do not always allow proper identification of the trademarks that were registered to brand a large variety of food products under the same trademark. For example, the firms that were classified in the official reports under the trademark title of canned food might have branded canned olive oil, among many other products, although this is not always stated in the sources.
} 
So, did the brand become a valuable asset that had to be legally defended, as Mira Wilkins and other scholars have argued? ${ }^{38}$ The evidence suggests an affirmative answer to this question, at least as far as the leading Mediterranean exporters are concerned. Indeed, by the turn of the twentieth century, some Italian firms had already brought legal action against other firms accused of misbranding practices, ${ }^{39}$ and the same was true in the interwar period. In early 1932, the well-known Italian firm F. Bertolli \& Co. accused Stefano Crisafulli and associates of having sold olive oil in packages imitating the name and, above all, the design of the Bertolli brand, and the Supreme Court of New York found in its favour. A few months later, the United Cicchetti Stores, Inc., P. Cicchetti \& Co. and Nazareno Pichione \& John of New York were also found guilty and fined after another suit brought by Francesco Bertolli. According to the injunction granted by the Supreme Court, the defendants were selling Bertolli's original cans which they had punctured and refilled with inferior oils. ${ }^{40}$

\section{Problems of quality uncertainty and fraud}

This evidence of firms protecting their brands through court actions brings us to a more general issue, which, in addition, helps to explain why olive oil for cooking and dressing continued, in the main, to be exported from southern Europe to the Americas in cans and bottles as a consumer-ready product. This issue is quality uncertainty and fraud. Though not always successful, bottling, canning and branding were in fact strategies designed to overcome the major problems of quality and fraud..$^{41}$

In the US, as well as in other countries in America with a large olive oil consumption, fraud became a major concern for those in the olive oil business. Indeed, there is abundant evidence of this from the end of the nineteenth century onwards, when adulterated olive oil was being packaged inside the country and sold as pure olive oil - a practice strongly condemned by the Italian Chamber of Commerce in New York. ${ }^{42}$

\footnotetext{
${ }^{38}$ Wilkins, 'The neglected'. For a dissenting view, Higgins and Tweedal, 'Asset'. For the protection of firms' brand through court actions see, among others, Duguid, 'Developing', Duguid, 'French', Higgins and Mordhorst 'Reputation', and for the legal use of the word 'sherry', Fernández, 'Unsuccessful'. On the responses of British multinationals in roder to protect the global reputation of their brands between 1870 and 1929, see da Silva Lopes and Casson, 'Brand'.

${ }^{39}$ Camera di Commercio Italiana in New York (hereafter CCINY), Nel cinquentenario, 129.

${ }^{40}$ OAA, 5, No. 3 (March, 1932), 8. Other examples include actions brought by P. Sasso \& Figli and Filippo Berio \& Co., two other well-known Italian exporters from Oneglia (Liguria) and Lucca (Tuscany) respectively. In the case of Sasso, the defendants were again the United Cicchetti Stores, Inc., P. Cicchetti\& Co. and Nazareno Pichione \& John in New York, who were accused of both filling Sasso's cans with inferior olive oils and selling a blend consisting mainly of cottonseed oil in cans which - Sasso claimed were deceptively coloured and labelled to imitate his brand. The lawsuit brought by Filippo Berio was against A. Ferrara \& Bros, who ran a grocery store. This time the defendant admitted, first, packing mixtures of sesame oil with olive oil and selling these mixtures in cans supplied by the Superior Can Co., and, second, attaching labels with the word 'Tiberio' and 'Luca \& Co.', in an attempt, according to the plaintiffs, to imitate the brand name of Berio from Lucca.

41 These strategies have been well documented for the wine industry. See for exemple Duguid, 'Developing'; Duguid, 'Networks'; Fernández, 'Unsuccessful'; Simpson, 'Selling', and Simpson, 'Too little'.

${ }^{42}$ CCINY, Nel cinquentenario, 160.
} 
Of course, olive oil was not the only product that suffered from adulterations. ${ }^{43}$ To prevent this and other fraudulent practices, the US authorities passed the Pure Food and Drug Act on 30 June $1906 .{ }^{44}$ This Act permitted blends of olive oil with other vegetable oils but stated that this fact had to be clearly labelled on the package, and also punished illegal mixtures of olive oil as well as misbranding, short sizing and other fraudulent practices. Finally, it established that foods and drugs offered for sale in the US, including olive oil arriving from foreign countries must undergo examination by the Bureau of Chemistry of the Department of Agriculture, or under the direction and supervision of this Bureau, for the purpose of determining whether these articles were adulterated or misbranded.

Nonetheless, fraudulent practices in olive oil seem to have continued, especially among (small) local packagers and dealers. During the second annual meeting of the Olive Oil Association of America, held in New York on 4 April 1922, the president of the Association's fraud committee announced that the committee had uncovered a large number of fraudulent practices in packaging and trading. These practices took two main forms: attaching place symbols on containers to suggest that they contained pure olive oil, when in fact they only contained other cheaper vegetable oils, and placing adulterated olive oil in real olive oil barrels, which in a number of cases were purchased from secondhand dealers. Seven years later, the former chief of the New York branch of the Bureau of Chemistry of the US Department of Agriculture stated that between 1924 and 1928 an enormous number of violations had been committed by dishonest domestic packers and mixers, of which only 175 were brought to the Federal courts. ${ }^{45}$ In 1932, Charles A. Tossi, president of the Olive Oil Association of America, called attention to this problem; he reported several recent cases and insisted that the economic crisis was leading consumers to prioritise the price of products rather than their quality, a situation which played into the hands of dishonest packagers and dealers. ${ }^{46}$

By contrast, olive oil imported either in tins or in bulk from producing countries does not appear to have been adulterated or misbranded. This was not only because exporting firms were interested in protecting their brands in the US market, but also because of the stricter controls carried out by US customs officers, who from 1906 onwards were able to apply the rules of the Pure Food and Drug Act. The evidence is conclusive in this respect, although it is true that the opposite was occasionally claimed. ${ }^{47}$

\footnotetext{
${ }^{43}$ See, among others, Dupré, 'If it's yellow' for the case of butter in north America between the 1880s and the 1940s, and Stanziani, 'Negotiating' for wine, butter, and milk adulteration in France between 1870 and 1914.

${ }^{44}$ Wood, 'The Strategic'. For a more general approach to pure food regulation, see, for example, Law, 'The Origins' and Stanziani, 'Negotiating'.

${ }^{45}$ US Congress, Tariff Act, 243.

46 Tossi, 'Protect Sales'. As in the early 1920s, many cases of fraud still consisted in repackaging mixtures of olive oil with other cheaper vegetable oils, which were sold in cans labelled with foreign names and symbols in an attempt to mislead the buyer. Together with this 'traditional' fraud, another more simple violation was becoming common: the short-filling of the containers. The most sophisticated fraud, however, consisted of blending olive oil with tea oil, a mixture that was difficult to detect by traditional chemical analysis, something which only became possible in 1936. CCINY, Nel cinquentenario, 129. Finally, misbranding practices were not uncommon either. See, for example, OAA, 5, No. 3 (March), 1932, 5, 9 and Servicio Informativo de la Federación de Exportadores de Aceite de Oliva de España (hereafter SIFE), Reports No. 1,494 (1932), 1,546 (1932) and 1,547 (1932).

${ }^{47}$ For example, in 1926, Italian olive oil exporters (and importers) were accused of introducing adulterated olive oil to the US. These accusations mobilised both those involved in the business and the Italian Chamber
} 
In 1905, detailed investigations made by the Bureau of Chemistry of the US Department of Agriculture concluded that the adulteration of foreign olive oil imported into the US was of little importance. The Bureau found that in the first inspection only five of the 61 samples obtained from the customs officers contained oils other than olive oil, while a second inspection showed that only nine samples out of 250 contained cottonseed oil. On the other hand, oils bought on the market and bearing labels indicating a foreign origin were found to be quite extensively adulterated with cottonseed oil. According to the Bureau of Chemistry, these adulterated oils bearing foreign labels appeared to have been labelled and adulterated after leaving the port of entry and were probably produced by domestic packagers or dealers rather than by foreign exporters or producers. ${ }^{48}$

In 1929, the Director of Regulatory Work in the Food, Drug and Insecticide Administration of the US Department of Agriculture, who was in charge of examining the olive oil entering the US, reached a similar conclusion. According to him, foreign olive oil, whether imported in tins or in bulk, rarely, if ever, arrived adulterated with foreign vegetable oils. Of all the records of the Administration for the period 1924-1928, only three showed olive oil adulteration at the time of importation; this probably represented around $1 \%$ of the total olive oil imported from abroad. ${ }^{49}$ And in 1932, during a meeting with olive oil importers, the representative of the Federal Administration made it clear that the 1931 customs statistics had recorded only 992 boxes of foreign olive oil imported in tins presenting misbranding and short sizing, that is, around $1 \%$ of total olive oil imports. Interestingly, the representative reported that these violations were generally associated with tins addressed to small, local distributors and that none of them involved either well-known brands or larger importers. ${ }^{50}$

In the light of the available evidence, it seems fair to conclude that olive oil packaged, branded and shipped from Europe, mostly by Mediterranean exporting firms, offered consumers a certain guarantee in terms of quality and, therefore, a sort of quality premium. In all likelihood, this could not always be said of the olive oil packaged and labelled in the US. Branding and strict customs controls seem to have been successful responses to the problems of quality uncertainty and fraud. In the words of a leading member of the Olive Oil Association of America, in 1929 the American

"consumer knows that every shipment of olive oil imported in the containers in which it is sold, is protected by careful and stringent examinations by the Department of Agriculture. The buyer knows that he has an assurance that the oil [which] these tins contain, is pure olive oil; that the volume of the contents is as specified on the tins; that it is full in measure; that it is absolutely free from illegal mixtures; that the possibility of fraud is minimised to the point of zero." 51

of Commerce in New York. They probably also led Tossi to call the matter to the attention of the members of his association and to recommend that the product, either in cans or in bulk, should be imported directly from well-known and credited exporting firms even if this proved more expensive. See CCINY, Nel cinquentenario, 149 and SIFE, Supplement to the Report No. 199 (1927), copied from a letter sent by Tossi to the members of the Olive Oil Association of America on 2 September 1927.

48 Tolman and Munson, 'Olive oil'. 62.

${ }^{49}$ US Congress, Tariff Act, 245-46.

${ }^{50}$ SIFE, Reports No. 1,494 (1932) and 1,495 (1932), originally published in OAA, volume V, 1932.

${ }^{51}$ US Congress, Tariff Readjustment, 716. 
Although probably a slight exaggeration, the statement appears to be correct in general terms. One would expect consumption of olive oil packaged and labelled abroad to grow and to gain a share in the US market. This is precisely what the available foreign trade data suggest during the 'roaring twenties' (Figure 6). Indeed, after the exceptional years of World War I, the aggregate consumption of the olive oil that was canned and branded in the Mediterranean basin increased more rapidly than total consumption of edible olive oil: whereas between 1920-24 and 1925-29 it rose by almost 60\%, bulk imports increased by only around $15 \%$.

Figure 6. Imports of olive oil in cans, bottles and packages of less than 5 gallons for domestic consumption into the US, 1905-1929 (five-year averages)

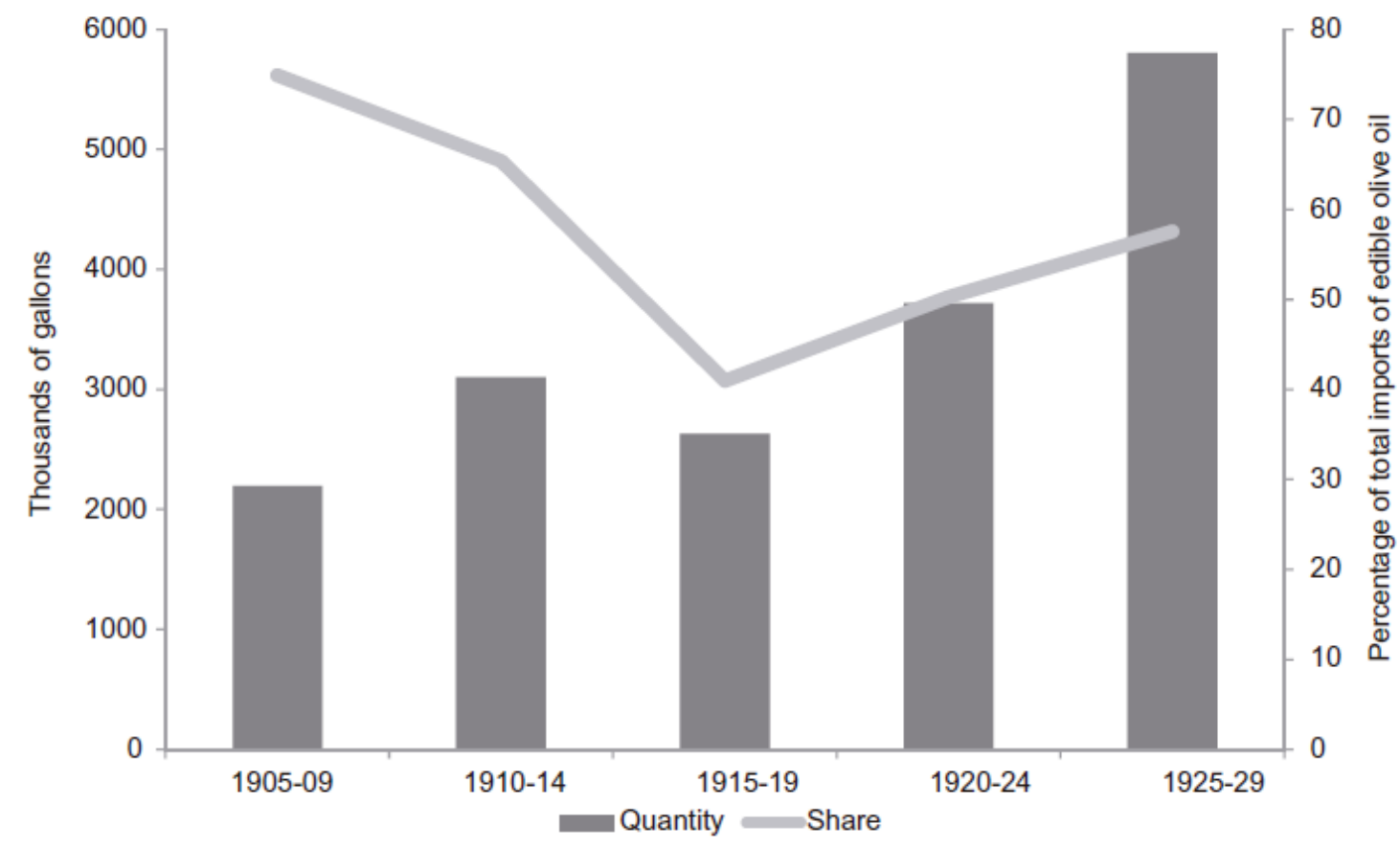

Notes and Sources: The Foreign, various issues.

Of course, this does not mean that the reputation of imported bulk olive oil suffered. To start with, as already mentioned, customs controls contributed to reducing fraud in this segment of the market. Moreover, because of the characteristics of the product, the quality of bulk olive oil could vary from one year to another and from one region to another, and so consumers were in need of information on current standards. The exporter provided this information and, to some extent, the exporter's name usually became a guarantee for product quality, as illustrated by the commercial correspondence of Hijos de J. Sabater, a firm based in an area of Spain which produced high-quality olive oils. ${ }^{52}$ If the exporter's

\footnotetext{
52 In 1929, A. E. Rittwagen, Sabater's agent in New York, reported that in the US the (Catalan) name of Gasull, the owner of the firm Establecimientos Félix Gasull, S.A., was associated with a very high-quality olive oil. Rittwagen regretted that the same could not be said of Sabater, suggesting the existence of a connection between the exporter's name and product quality. Letter dated 19 March 1928. ACBC. FS. Letters to and from A. E. Rittwagen, New York (1923-1933), boxes 4 and 165 M respectively.
} 
name was an indication of product quality, the geographical origin of the oil provided further information in this respect as well as with regard to the product's potential uses. ${ }^{53}$

In short, the cause of the problem of fraud and adulteration was not the olive oil arriving in bulk from the Mediterranean basin, but the practices of dishonest domestic packers and mixers. This situation was highlighted by several Spanish reports on the current state and future prospects of the US olive oil market in the mid-1930s. ${ }^{54}$

Was the US the only importing country where adulteration and other fraudulent practices could be found? The answer is clearly no, and many examples could be given to show this. Perhaps the most important thing to note is that, as in the US, chemical analyses and controls on imported olive oil became the rule rather than the exception during the first third of the twentieth century. This was so in many European countries as well as in the largest Latin American markets for olive oil. Nevertheless, it was only during World War I and, especially, from the early 1920s onwards, that more protective legislation against misbranding and illegal blending was passed in the countries of Latin America.

The Uruguayan authorities, for example, passed laws in 1914 (the Law of 2 December 1914 and the Regulations of 14 June 1915) pertaining to olive oil imports. According to article three of these Regulations, blends of olive oil with other vegetable oils were allowed, but this fact had to be clearly labelled on the package in which they were sold. In addition to the weight, cans containing blends of olive oil and other edible oils also had to specify the proportion of vegetable oils in blends. ${ }^{55}$ In 1917, the Argentinian Ministry of Finance passed two laws (26 February 1917 and 16 August 1917) making chemical analysis mandatory for foreign olive oil before entering the country. In addition, in 1919 the local authorities of Buenos Aires established a new Decree (26 November 1919) regulating olive oil production and trade in the city, which also insisted on chemical analysis before the oil could be sold in Buenos Aires. Both producers and traders were also required to label and brand the cans properly, by including the type of product, its brand name, the names of the importer and the exporter, the weight of the can, the place of production as well as the kinds of oils used if the product was blended. The right to include the words 'olive oil' on the cans was reserved to pure olive oil. ${ }^{56}$ Finally, a new Decree passed by the Federal authorities on 25 October 1926 maintained part of the former legislation on the olive oil trade but authorised a controversial practice: edible vegetable oils could be sold in the domestic market without having to specify the composition of the product, and their containers could use the words 'Pure edible oil'.

\footnotetext{
${ }^{53}$ In 1921, the representative of the Pompeian Sea Food Co. claimed that the packagers of sardines and tuna fish in California used almost three-quarters of a million gallons of olive oil a year (around 2.6 thousand metric tons), but that all of it had to be imported because the oil produced in California contained a high percentage of free fatty acid. US Congress, Tariff Information, 241. While this statement probably requires some qualification, what is clear is that packagers of fish required a high-standard product, although they did not always make use of the same grades of olive oil. In fact, fish-canners' demands for olive oil tended to differ, not only because of the particular variety of olive oil used in canning but also because of the quantity of refined olive oil introduced in the can and the amount of vegetable oils other than olive oil that they used.

${ }^{54}$ AOE, 6, No. 70 (September 1934), 310; AOE, 7, No. 74 (January, 1935), 455; AOE, 7, No. 81

(September, 1935), 716.

${ }^{55}$ Ministerio de Estado (hereafter ME), Estudio comercial, 8-9.

${ }^{56}$ ME (1920), pp. 21-29, for a detailed review of the Argentinian legislation between 1913 and 1920.
} 
Not surprisingly, this legislation was widely criticised by both importers and exporters. ${ }^{57}$ As in Argentina, the Chilean government established a new legal framework in 1918 with the Law of 9 October, which not only strengthened the control of foreign olive oil by means of chemical analysis, but also reserved the words 'olive oil' and 'edible oil' for pure olive oil. ${ }^{58}$

Unfortunately, it is difficult to establish how far fraud and irregular practices in olive oil trade decreased as a consequence of this legislation. Whatever the case, the legislation represented an important step forward for both consumer protection and the exporting firms' reputation, since stricter controls and regulations offered a higher guarantee of the quality of the olive oil produced, labelled and traded in small tins directly from the main producing and exporting areas. This was the conclusion of the Spanish commercial attaché in South America in 1925. After drawing attention to the large-scale fraud and adulteration in Brazil, he proposed a partial solution to the problem: the passing of legislation for olive oil and other foodstuffs similar to that existing in Argentina and Uruguay. ${ }^{59}$

\section{Conclusions}

This article has provided new evidence of the use of branding and modern marketing in the international markets for food products between the 1870s and the 1930s. Using olive oil as a case study, it quantifies the expansion of export branding, shows the geographical patterns of this expansion and discusses its determinants. In particular, this research has demonstrated that the world trade of packaged olive oil - a proxy for branded olive oil increased more rapidly than the total world olive oil trade from the 1870s onwards. It has shown that, in contrast to the Old World, most of the olive oil exported to the Americas consisted of packaged (and, therefore, branded) olive oil. Finally, it has been argued that the extensive application of modern marketing techniques when the product was exported to the other side of the Atlantic was the result of three interconnected factors: the mass migration from southern Europe in the late nineteenth century and the formation of a new market in the Americas; transformations in the commodity chain, the emergence of ownbranding strategies, and the growing demand for variety; and lastly the problems of product uncertainty and fraud, and how both authorities and firms responded to them.

A number of more general conclusions can also be drawn from this research. First, the use of foreign trade data for assessing the growth of branding in export trade offers new insights into marketing - complementing, and probably extending, previous findings based on the use of trademark registration figures. Thus, while the estimates presented in this article reflect an enormous increase in export branding since the 1870s, they also allow an assessment of the participation of canned and branded olive oil in the total world

\footnotetext{
${ }^{57}$ The Spanish Chamber of Commerce in Buenos Aires opposed this new legislation forcefully; the law was confusing, since it not only failed to protect olive oil against adulterations but also showed that the Argentinian authorities were exclusively interested in protecting the interests of the national industry of vegetable oil rather than the domestic consumers. The main arguments of the Spanish Chamber of Commerce are summarised in SIFE, Reports No. 45 (1927), No. 137 (1927), No. 244 (1928), No. 605 (1929), No. 845 (1930) and Supplement to the Report, No. 1,028 (1930). For an opposing view in SIFE, Supplement to the Report No. 193 (1927), Supplement to the Report No. 358 (1928) and Supplement to the Report No. 352 (1928).

${ }^{58} \mathrm{ME}$, El aceite español, 21-23.

${ }^{59}$ Consejo de Economía Nacional, El aceite de oliva, 10-12.
} 
olive oil trade. The use of foreign trade data also sheds new light on patterns of export marketing in the different continents. This is another interesting finding; in his analysis of the world wine industry, James Simpson stressed the existence of important differences in the production and marketing of wines between the Old and New World. ${ }^{60}$ Our research has demonstrated that these differences across continents are also found in other industries and other fields, in this case the export marketing of olive oil.

Second, this study provides further evidence regarding the debate on the purpose of branding and modern marketing. This important topic has generated a considerable volume of research. A first area of debate is the informative or persuasive nature of branding. ${ }^{61}$ A second area of discussion is the role of modern marketing in the competitive strategy of firms and industries, either as an entry barrier or, in the case of branding, as part of the innovative process. ${ }^{62}$ While information, persuasion and competitiveness all played a role in the expansion of olive oil export branding, the results presented in this article expand on some of these issues, showing that mass migration fostered the transformation of selling and marketing methods. In creating a new market for olive oil, migration challenged the competitive strategies of exporting firms which now found themselves obliged to inform, persuade and compete for consumers who were far away from the areas of production. Later, migrants also appear to have become active actors in the transformation of the commodity chain in response to the demand for variety and the changing costs of packaging, storing and blending. Like many other studies, this article has also found that export branding went hand in hand with the problem of quality uncertainty and fraud. Nevertheless, and in contrast to the conclusions reached for other Mediterranean products, ${ }^{63}$ in the case of olive oil the strategy of packaging and branding in its areas of production rather than in the consuming markets appears to have been relatively effective in maintaining and increasing the flows of packaged and branded olive oil from the Old World to the Americas. This strategy was boosted by the emergence of new food regulations and strict customs controls on the other side of the Atlantic.

Third, the findings of this study illustrate the enduring nature of international marketing patterns and how historical analysis can aid the understanding of current situations. In the early 2010s, the US consumed about 300,000 metric tonnes of olive oil, far more than any other non-Mediterranean country. More than nine-tenths of this consumption consisted of imported olive oil, of which about two-thirds arrived in consumer-ready bottles and the rest of imports were shipped in bulk. As a bulk product, olive oil is consumed by bottling plants, which 'package the products for sale to retail businesses, under brand names or private labels (...), or to the food service segment'. The marketing characteristics of the US market are considered by some experts to be unique 'among countries that import significant quantities of olive oil'. ${ }^{64}$ This article has documented the historical roots of this 'marketing uniqueness'.

\footnotetext{
${ }^{60}$ Simpson, 'The emergence'.

${ }^{61}$ In the particular case of branding, see, for example, Wilkins, 'When' and Cason, 'Brands'.

${ }^{62}$ A short review of the literature on product differentiation and entry barriers can be found in RamonMuñoz, 'Product'.

${ }^{63}$ See, for example, Simpson, 'Selling', for fortified wines in Britain in the nineteenth century, and Fernández, 'Unsuccessful', for the case of the sherry industry in the twentieth century.

${ }^{64}$ US International Trade Commission, 'Olive oil', 4.3.
} 


\section{Acknowledgments}

Previous versions of this article were presented and discussed at the 16th Annual Conference of the European Business History Association (Paris, 2012), the 14th International Conference on Agricultural History (Badajoz, 2013), the International Seminar 'Brand and its History: Economic, Business and Social Value' (Madrid 2014) and the 11th International Conference of the Spanish Economic History Association (Madrid, 2014). I would like to thank the participants at these meetings, as well as Jaime Reis, the editors of this special issue and the anonymous referees of this journal for their useful comments. The usual disclaimer applies.

\section{Disclosure statement}

No potential conflict of interest was reported by the author

\section{Funding}

This work was supported by Spanish Ministry of Economy (MINECO) and European Regional Development Fund (ERDF) [grant number HAR2015-64769-P].

\section{Notes on contributor}

Ramon Ramon-Muñoz is Associate Professor in Economic History at the Department of Economic History, Institutions, Politics and World Economy, University of Barcelona.

\section{References}

Alexander, Nicholas, and Gary Akehurst. "Introduction: The Emergence of Modern Retailing, 1750-1950.”Business History 40, no. 4 (1998): 1-15. doi: $10.1080 / 00076799800000335$.

Berghoff, Hartmut, Philip Scranton, and Uwe Spiekermann. "The Origins of Marketing and Market Research: Information, Institutions, and Markets." In The Rise of Marketing and Market Research, edited by Hartmut Berghoff, Philip Scranton, and Uwe Spiekermann, 1-26. New York: Palgrave Macmillan, 2012.

Câmara Portuguesa de Comércio e Indústria do Rio di Janeiro. Inquérito para a expansâo do comercio português no Brasil [Inquiry into the expansion of the Portuguese trade in Brazil]. Porto: Imprensa Portuguesa, 1916.

Camera di Commercio Italiana in New York. Nel cinquentenario della Camera di Commercio Italiana in New York [On the fiftieth anniversary of the Italian Chamber of Commerce in New York]. New York: Camera di Commercio Italiana, 1937.

Casson, Mark. "Brands. Economic Ideology and Consumer Society." In Adding value: brands and marketing in food and drink, edited by Geoffrey Jones and Nicholas Morgan, 41-58. London: Routledge, 1994.

Chandler, Alfred D. The Visible Hand. The Managerial Revolution in American Business. Cambridge, MA: Harvard University Press, 1977.

Chandler, Alfred D. Scale and Scope. The Dynamics of Industrial Capitalism. Cambridge, MA, and London: Harvard University Press, 1990. 
Church, Roy. "New Perspectives on the History of Products, Firms, Marketing, and Consumers in Britain and the United States since the Mid-Nineteenth Century." The Economic History Review 52, no. 3 (1999): 405-435. doi:10.1111/1468-0289.00131.

Church, Roy. "Advertising Consumer Goods in Nineteenth-Century Britain: Reinterpretations." The Economic History Review 53, no. 4 (2000): 621-645. doi:10.1111/1468-0289.00172.

Church, Roy, and Andrew Godley. "The Emergence of Modern Marketing: International Dimension.” Business History 45, no. 1 (2003): 1-5. doi:10.1080/713999301.

Consejo de Economía Nacional. El aceite de oliva en el mercado del Brasil. Por Emilio Boix. Madrid: Imprenta del Ministerio de Estado, 1925.

Duguid, Paul. "Developing the Brand: The Case of Alcohol, 1800-1880." Enterprise and Society 4, no. 3 (2003): 488-500. doi:10.1017/S1467222700012660.

Duguid, Paul. "Networks and Knowledge: The beginning and End of the Port Commodity Chain, 1703-1860." Business History Review 79, no. 3 (2005): 453-466. doi: $10.1017 / \mathrm{S} 0007680500081423$.

Duguid, Paul. "French Connections: The International Propagation of Trademarks in the Nineteenth Century." Enterprise and Society 10, no. 1 (2009): 3-37. doi:10.1093/es/khn104.

Duguid, Paul, Teresa da Silva Lopes, and John Mercer. "Reading Registrations: An Overview of 100 Years of Trade Mark Registrations in France, the United Kingdom, and the United States." In Trademarks, Brands and Competitiveness, edited by Teresa Da Silva Lopes and Paul Duguid, 9-30. London: Routledge, 2010.

Dupré, Ruth. "If It's Yellow, It Must Be Butter?: Margarine Regulation in North America Since 1886." The Journal of Economic History 59, no. 2 (1999): 353-371. doi:10.1017/S0022050700022865.

El Aceite de Oliva de España. Órgano de la Federación de Exportadores de Aceite de Oliva de España [Spanish Olive Oil. Organ of the Spanish Olive Oil Exporters Federation]. Madrid, 1929-36, various issues.

Espuny, Tomás. De Gallur a Nueva York. Diario de viaje (1929) [From Gallur to New York. Travel Diary (1929)]. Zaragoza: Ayuntamiento de Gallur, 2002.

Ferenczi, Imre, and Walter F. Willcox. International Migrations, Volume I: Statistics. New York: National Bureau of Economic Research, 1929.

Fernández, Alejandro E. Un "mercado étnico" en el plata. Emigración y exportaciones españolas a la Argentina, 1880-1935 [An "ethnic market" in the Plata. Emigration and Spanish exports to Argentina,1880-1935]. Madrid: Consejo Superior de Investigaciones Científicas, 2004.

Fernández, Eva. "Unsuccessful Responses to Quality Uncertainty: Brands in Spain's Sherry Industry,1920-1990.” Business History 52, no. 1 (2010): 100-119. doi: $\underline{10.1080 / 00076790903469638 .}$. 
Fullerton, Ronald A. "How Modern is Modern Marketing? Marketing's Evolution and the Myth of the 'Production Era'." Journal of Marketing 52, no. 1 (1988): 108-125. doi: $10.2307 / 1251689$.

Hatton, Timothy J., and Jeffrey G. Williamson. "The Issues." In The Age of Mass Migration. Causes and Economic Impact, edited by Timothy J. Hatton and Jeffrey G. Williamson, 7-31. New York and Oxford: Oxford University Press, 1998.

Higgins, David M., and Mads Mordhorst. "Reputation and Export Performance: Danish Butter Exports and the British Market, c.1880-c.1914." Business History 50, no. 2 (2008): 185-204.doi:10.1080/00076790701868601.

Higgins, David, and Geoffrey Tweedale. "Asset or Liability? Trade Marks in the Sheffield Cutlery and Tool Trades." Business History 37, no. 3 (1995): 1-27. doi: $10.1080 / 00076799500000088$.

Higgins, David M. "The Making of Modern Trade Mark Law: The UK, 1860-1914. A Business History Perspective." In Trade Marks and Brands. An Interdisciplinary Critique, edited by Lionel Bently, Jennifer Davis, and Jane C. Ginsburg, 42-62. Cambridge: Cambridge University Press, 2008.

International Institute of Agriculture. International Yearbook of Agricultural Statistics. Rome: International Institut of Agriculture, 1909-39.

Law, Marc T. "The Origins of State Pure Food Regulation.” Journal of Economic History 63, no. 4 (2003):1103-1130. doi:10.1017/S0022050703002547.

Lluch, Andrea. "Marca registrada: Reflexiones sobre el uso de las marcas comerciales, el consumo y la comercialización de bienes en el mundo rural argentino (1900-1930)."

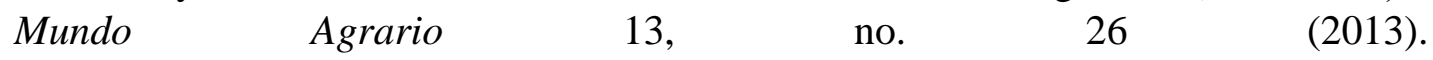
http://www.memoria.fahce.unlp.edu.ar/art_revistas/pr.5691/pr.5691.pdf.

Mercer, John. "A Mark of Distinction: Branding and Trade Mark Law in the UK from the 1860s." Business History 52, no. 1 (2010): 17-42. doi: $10.1080 / 00076790903281033$.

Mercurio. Revista Comercial Ibero-Americana [Mercurio. Ibero-American Trade Journal]. Barcelona, 1913, various issues.

Ministerio de Estado. Estudio comercial sobre la República Oriental del Uruguay. Por Emilio Boix [Trade Report on the Oriental Republic of Uruguay. By Emilio Boix]. Madrid: Imprenta del Ministerio de Estado, 1919.

Ministerio de Estado. Los aceites en la República Argentina. Por Emilio Boix [Oils in the Argentine Republic. By Emilio Boix]. Madrid: Imprenta del Ministerio de Estado, 1920.

Ministerio de Estado. El aceite español en Chile. Por Cayetano Rosich [The Spanish olive oil in Chile. By Cayetano Rosich]. Madrid: Imprenta del Ministerio de Estado, 1922.

Ministero di Agricoltura, Industria e Commercio. Il comercio dell'olio d'oliva all'estero. Parte II [The olive oil trade abroad. Part II]. Roma: Tipografia Nazionale di G. Bertero e C., 1913. 
Olive Oil. Official Organ of the Olive Oil Industry Published Monthly by the Olive oil Association of America/Olive Oil and Imported Foods. New York: Official Organ of the Olive Oil Association of America, 1929-1935.

Ramon-Muñoz, Ramon. "Migration and Trade: The Case of Southern European Immigration and Olive Oil Imports in the Americas (1875-1930)." Paper presented at the 8th Conference of the European Historical Economics Society (EHES), Geneva, Graduate Institute of International and Development Studies, September 4-5, 2009.

Ramon-Muñoz, Ramon. "Product Differentiation and Entry Barriers: Mediterranean Export Firms in the American Markets for Olive Oil Prior to World War II." Business History 52, no. 3 (2010): 390-416.doi:10.1080/00076791003721613.

Ramon-Muñoz, Ramon. Patterns of Export Marketing in the International Market for Olive Oil, 1870s-1930s.Mimeo, Barcelona, 2016.

Ramon-Muñoz, Ramon. "Specialization in the International Market for Olive Oil before World War II." In The Mediterranean Response to Globalization before 1950, edited by Sevket Pamuk and Jeffrey G Williamson, 159-198. London and New York: Routledge, 2000.

Sáiz, J. Patricio, and Paloma Fernández Pérez. "Catalonian Trademarks and the Development of Marketing Knowledge in Spain, 1850-1946." Business History Review 86, no. 2 (2012): 239-260. doi:10.1017/S0007680512000396.

Servicio Informativo de la Federación de Exportadores de Aceite de Oliva de España [Information Service of the Spanish Olive Oil Exporters Federation]. Reports and Supplements to the Reports for the Years. Madrid, 1927-35, various issues.

da Silva Lopes, Teresa. Global Brands: The Evolution of Multinationals in Alcoholic Beverages. New York: Cambridge University Press, 2007.

da Silva Lopes, Teresa, and Mark Casson. "Brand Protection and the Globalization of British Business." Business History Review 86, no. 02 (2012): 287-310. doi:10.1017/S0007680512000414.

da Silva Lopes, Teresa, and Paulo Guimaraes. "Trademarks and British Dominance in Consumer Goods,1876-1914." Economic History Review 67, no. 3 (2014): 793-817. doi: $10.1111 / 1468-0289.12039$.

Simpson, James. "Selling to Reluctant Drinkers: The British Wine Market, 1860-1914." The Economic History Review 57, no. 1 (2004): 80-108. doi:10.1111/j.00130017.2004.00273.x.

Simpson, James. "Too Little Regulation? The British Market for Sherry, 1840-90." Business History 47, no.3 (2005): 367-382. doi:10.1080/00076790500055988.

Simpson, James. Creating Wine. The Emergence of a World Industry, 1840-1914. Princeton: Princeton University Press, 2011.

Stanziani, Alessandro. "Negotiating Innovation in a Market Economy: Foodstuffs and Beverages Adulteration in Nineteenth-Century France." Enterprise and Society 8, no. 02 (2007): 375-412. doi:10.1017/S1467222700005899 
Tedlow, Richard S. New and Improved: The Story of Mass Marketing in America. New York: Basic Books,1990.

Tedlow, Richard S. "The Fourth Phases of Marketing: Marketing History and the Business World Today." In The Rise and Fall of Mass Marketing, edited by Richard S. Tedlow and Geoffrey Jones, 8-35. London and New York: Roudledge, 1993.

Tolman, L. M., and L. S. Munson. "Olive oil and its substitutes." Bureau of Chemistry Bulletin, no. 77 (1905):1-62.

Tosi, Charles A. "Protect Sales of Pure Olive oil." Olive Oil and Imported Foods. Official organ of the Olive Oil Association of America V, no. 8 (1932): 1-3.

US Congress. Tariff Schedules. Vol. I. Washington: Government Printing Office, 1913.

US Congress. Tariff Information, 1921. Part I. Washington: Government Printing Office, 1921.

US Congress. Tariff Act of 1929. Vol. I. Washington: Government Printing Office, 1929.

US Congress. Tariff Readjustment, 1929. Vol. I. Washington: Government Printing Office, 1929.

US Department of Commerce and Labor. The Foreign Commerce and Navigation of the United States for the Year Ending. Washington: Government Printing Office, 1904/1905-1910/1911.

US Department of Commerce. The Foreign Commerce and Navigation of the United States for the Year Ending. Washington: Government Printing Office, 1911/19121929.

US International Trade Commission. "Olive Oil: Conditions of Competition between U.S. and Major Foreign Supplier Industries." Investigation No. 332-537, USITC Publication 4419, August 2013.

US Patent Office. Annual Report of the Commissioner of Patents for the Year... Washington: Government Printing Office, 1905-25.

US Patent Office. Index of Trademarks Issued from the United States Patent Office, 1935. Washington: Government Printing Office, 1935.

US Tariff Commission. Report to the President on Olive Oil. Washington: Government Printing Office, 1931.

Wilkins, Mira. "The Neglected Intangible Asset: The Influence of the Trade Mark on the Rise of the Modern Corporation." Business History 34, no. 1 (1992): 66-95. doi: $10.1080 / 00076799200000004$.

Wilkins, Mira. "When and Why Brand Names in Food and Drink." In Adding Value: Brands and Marketing in Food and Drink, edited by Geoffrey Jones and Nicholas Morgan, 15-40. London: Routledge, 1994. 
Williams, Bridget. "Multiple Retailing and Brand Image: An Anglo-American Comparison, 1860-1914." In Adding Value: Brands and Marketing in Food and Drink, edited by Geoffrey Jones and Nicholas Morgan, 291-309. London: Routledge, 1994.

Wood, Donna J. "The Strategic Use of Public Policy: Business Support for the 1906 Food and Drug Act." Business History Review 59, no. 3 (1985): 403-432. doi:https://doiorg.sire.ub.edu/10.2307/3114005. 